\title{
Progressive multifocal leukoencephalopathy after fingolimod treatment
}

Joseph R. Berger, MD, Bruce A. Cree, MD, PhD, Benjamin Greenberg, MD, Bernhard Hemmer, MD, Brian J. Ward, MDCM, Victor M. Dong, MD, and Martin Merschhemke, MD

Neurology ${ }^{\circledR}$ 2018;90:e1815-e1821. doi:10.1212/WNL.0000000000005529

\author{
Correspondence \\ Dr. Berger \\ joseph.berger@ \\ uphs.upenn.edu
}

\begin{abstract}
\section{Objective}

We describe the characteristics of the 15 patients with fingolimod-associated progressive multifocal leukoencephalopathy (PML) identified from the Novartis data safety base and provide risk estimates for the disorder.
\end{abstract}

\section{Methods}

The Novartis safety database was searched for PML cases with a data lock point of August 31, 2017. PML classification was based on previously published criteria. The risk and incidence were estimated using the 15 patients with confirmed PML and the overall population of patients treated with fingolimod.

\section{Results}

As of August 31, 2017, 15 fingolimod-treated patients had developed PML in the absence of natalizumab treatment in the preceding 6 months. Eleven (73\%) were women and the mean age was 53 years (median: 53 years). Fourteen of the 15 patients were treated with fingolimod for $>2$ years. Two patients had confounding medical conditions. Two patients had natalizumab treatment. This included one patient whose last dose of natalizumab was 3 years and 9 months before the diagnosis of PML. The second patient was receiving fingolimod for 4 years and 6 months, which was discontinued to start natalizumab and was diagnosed with PML 3 months after starting natalizumab. Absolute lymphocyte counts were available for 14 of the 15 patients and none exhibited a sustained grade 4 lymphopenia $(\leq 200$ cells $/ \mu \mathrm{L})$.

\section{Conclusions}

The risk of PML with fingolimod in the absence of prior natalizumab treatment is low. The estimated risk was 0.069 per 1,000 patients (95\% confidence interval: $0.039-0.114$ ), and the estimated incidence rate was 3.12 per 100,000 patient-years ( $95 \%$ confidence interval: 1.75-5.15). Neither clinical manifestations nor radiographic features suggested any unique features of fingolimod-associated PML. 


\section{Glossary}

CI = confidence interval; JCV = John Cunningham virus; $\mathbf{M S}=$ multiple sclerosis; PML = progressive multifocal leukoencephalopathy.

Progressive multifocal leukoencephalopathy (PML) is a rare opportunistic infection of the CNS caused by reactivation of a latent John Cunningham virus (JCV), with a prevalence of 0.2 cases per 100,000 persons in the general population. ${ }^{1}$ In 2005, PML was confirmed in 3 patients participating in natalizumab clinical trials of multiple sclerosis (MS) $)^{2,3}$ and Crohn disease, ${ }^{4}$ disorders that were not previously associated with PML. As of August 2017, 749 confirmed cases of PML associated with natalizumab have been reported ${ }^{5}$ and, further, in 5 dimethyl fumarate-treated patients with MS. ${ }^{6}$ This has raised the possibility that there has been an increased risk of PML in patients with MS treated with immunosuppressive or immunomodulatory agents.

Fingolimod is a sphingosine 1-phosphate receptor modulator approved for the treatment of relapsing forms of MS. Fingolimod prevents the egress of $\mathrm{T}$ and $\mathrm{B}$ lymphocytes from lymph nodes and reduces the infiltration of autoaggressive cells into the CNS.,

Although peripheral blood lymphocyte counts declined by $73 \%$ from baseline values within 1 month of drug initiation, ${ }^{9,10}$ consistent with the pharmacodynamic action of fingolimod, serious or opportunistic infections have only been infrequently observed in the postmarketing setting. To date, no correlation has been shown between absolute lymphocyte counts and the incidence of serious or opportunistic infections. Since 2015, PML cases not attributed to prior exposure to immunosuppressants have been reported in fingolimod-treated patients. The US prescribing information was subsequently updated to include opportunistic infections including PML. ${ }^{11}$ Herein, we describe the characteristics of 15 PML cases reported in fingolimod-treated patients with MS.

\section{Methods}

The Novartis safety database was searched for PML cases using the following search terms (MedDRA [Medical Dictionary for Regulatory Activities], version 19.1) with a data lock point of August 31, 2017: progressive multifocal leukoencephalopathy, leukoencephalopathy, leukoencephalomyelitis, and JC virus granule cell neuronopathy. The PML cases were classified as "definite," "probable," "possible," or "not PML" based on the criteria presented by Berger et al. in $2014,{ }^{12}$ by an adjudication committee comprising experts in MS and PML. This classification is based on JCV DNA PCR status of CSF, MRI findings, and clinical presentation.

Overall patient exposure estimates were determined based on a combination of patient exposure to fingolimod in clinical trials together with an estimate of postmarketing patient exposure (which is calculated based on worldwide sales volume in kilograms of active substance sold during the period and the defined daily dose of $0.5 \mathrm{mg}$ ).

The incidence of PML in patients treated with fingolimod was estimated using the 15 confirmed PML cases and an overall population of patients treated with fingolimod. Patient characteristics were compiled based on the pharmacovigilance reports from the treating physicians held in the Novartis safety database, and patient identifiers are not revealed.

\section{Data availability}

These data are not from a clinical trial or specific study setup. It is rather based on postmarketing spontaneous reports made to Novartis in the context of routine pharmacovigilance. This reporting comes from various regions/countries with their respective data privacy laws. Data available in the Novartis safety database have been used to describe the carefully deidentified individual cases, and as such, no further data will be shared in either a repository or on request.

\section{Results}

In total, 15 confirmed PML cases-12 "definite" and 3 "probable"-for which prior immunotherapy is not implicated, were identified in the real-world setting. Based on data from 15 confirmed PML cases associated with fingolimod treatment alone, the estimated risk is 0.069 per 1,000 patients (95\% confidence interval [CI]: $0.039-0.114$ ) and the estimated incidence rate is 3.12 per 100,000 patient-years $(95 \%$ CI: 1.75-5.15). Details of the clinical features of the 15 PML cases are shown in the table.

\section{Demographics and baseline characteristics}

The patients were geographically dispersed across Europe ( $\mathrm{n}$ =6), North America $(n=5)$, and Asia $(n=4)$. Of the 15 patients, 11 were women. The mean patient age was 53 years (median: 53 years) and 5 patients were younger than 50 years. The duration of MS in these patients ranged from 4 to 35 years (considering those with known year of MS onset). Of the 15 patients with PML, 2 presented with confounding medical conditions (one with previous cancer and one patient with ulcerative colitis with prior immunosuppressive therapy). In addition, there were 2 patients who had received therapy with natalizumab; however, the contributory role of fingolimod in the occurrence of PML could not be excluded in these cases. The first patient had previous natalizumab exposure for 10 months, which was discontinued for 7 months, and then the patient received fingolimod treatment for 38 


\begin{tabular}{|c|c|c|c|c|c|c|c|c|c|c|}
\hline $\begin{array}{l}\text { Age } \\
\text { range, y }\end{array}$ & Sex & $\begin{array}{l}\text { MS duration } \\
\text { (at time } \\
\text { of PML } \\
\text { diagnosis), y }\end{array}$ & $\begin{array}{l}\text { Prior treatment for MS; } \\
\text { duration of washout of } \\
\text { prior treatment }\end{array}$ & $\begin{array}{l}\text { Fingolimod } \\
\text { exposure, } \\
\text { mo }\end{array}$ & $\begin{array}{l}\text { Compatible clinical } \\
\text { features }\end{array}$ & $\begin{array}{l}\text { Compatible MRI } \\
\text { findings }\end{array}$ & CSF PCR for JCV & $\begin{array}{l}\text { Clinical } \\
\text { symptoms/ } \\
\text { MRI findings/ } \\
\text { CSF PCR for JCV }\end{array}$ & $\begin{array}{l}\text { Certainty } \\
\text { of PML } \\
\text { diagnosis }\end{array}$ & ALC, cells/ $\mu \mathrm{L}$ \\
\hline $45-50$ & M & 5 & $\begin{array}{l}\text { Interferon } \beta \text {-1a and } \\
\text { corticosteroids; washout after } \\
\text { steroids } 7 \text { mo }\end{array}$ & 52 & Asymptomatic & Positive & $\begin{array}{l}\text { Positive (local lab } \\
\text { and NIH) }\end{array}$ & $-/+/+$ & Probable & $240-890$ \\
\hline $50-55$ & M & 14 & $\begin{array}{l}\text { Interferon } \beta-1 \mathrm{~b} \text {; washout } \\
\text { period a few days }\end{array}$ & 30 & $\begin{array}{l}\text { Walking instability, motor } \\
\text { clumsiness, cognitive } \\
\text { symptoms }\end{array}$ & Positive & $\begin{array}{l}\text { Positive (local lab } \\
\text { and NIH) }\end{array}$ & $+/+/+$ & Definite & $200-550$ \\
\hline $50-55$ & $\mathrm{~F}$ & 19 & $\begin{array}{l}\text { Glatiramer acetate, } \\
\text { corticosteroids, interferon } \\
\beta-1 \text { b; washout period } \\
\text { unknown }\end{array}$ & 35 & $\begin{array}{l}\text { Unusual memory problems, } \\
\text { later significant confusion and } \\
\text { slurred speech }\end{array}$ & Positive & $\begin{array}{l}\text { Positive (local lab } \\
\text { and NIH) }\end{array}$ & $+/+/+$ & Definite & $400-1,000$ \\
\hline $55-60$ & $\mathrm{~F}$ & 15 & $\begin{array}{l}\text { Interferon } \beta-1 \text { a; washout } \\
\text { period unknown }\end{array}$ & 54 & $\begin{array}{l}\text { Cognitive disorder, struggled } \\
\text { to finish thoughts and } \\
\text { misused words, fleeting visual } \\
\text { hallucinations }\end{array}$ & Positive & $\begin{array}{l}\text { Positive (local lab } \\
\text { and NIH) }\end{array}$ & $+/+/+$ & Definite & $200-670$ \\
\hline $50-55$ & $\mathrm{~F}$ & $\begin{array}{l}\text { At least } 8 \text { y } \\
\text { (exact duration } \\
\text { unknown) }\end{array}$ & $\begin{array}{l}\text { Natalizumab (duration } 10 \\
\text { mo); washout period } 7 \text { mo }\end{array}$ & 39 & $\begin{array}{l}\text { Weakness on right side of } \\
\text { body, difficulty speaking, } \\
\text { cognitive disorder, memory } \\
\text { impairment, aphasia }\end{array}$ & Positive & Positive & $+/+/+$ & Definite & $300-500$ \\
\hline $60-65$ & $\mathrm{~F}$ & 4 & $\begin{array}{l}\text { Interferon } \beta-1 \mathrm{~b} \text {; washout } \\
\text { period } 9 \text { mo }\end{array}$ & 29 & $\begin{array}{l}\text { Cognitive decline, especially } \\
\text { speech loss, forgetfulness }\end{array}$ & $\begin{array}{l}\text { MRI findings were } \\
\text { not typical; however, } \\
\text { PML could not be } \\
\text { ruled out }\end{array}$ & $\begin{array}{l}\text { Positive (local lab } \\
\text { and NIH) }\end{array}$ & $+/-/+$ & Probable & $411-580$ \\
\hline $30-35$ & $\mathrm{~F}$ & 20 & $\begin{array}{l}\text { Interferon } \beta-1 b \text {, interferon } \\
\beta-1 a \text {, glatiramer acetate; } \\
\text { washout period unknown }\end{array}$ & 46 & $\begin{array}{l}\text { Right-sided hemiplegia, } \\
\text { inappetence, loss of } \\
\text { sensation, aphasia, visual and } \\
\text { auditory hallucinations }\end{array}$ & Positive & $\begin{array}{l}\text { Positive (local lab } \\
\text { and NIH) }\end{array}$ & $+/+/+$ & Definite & $160-2,400$ \\
\hline $60-65$ & $\mathrm{~F}$ & 23 & $\begin{array}{l}\text { Interferon } \beta-1 a \text {; washout } \\
\text { period unknown }\end{array}$ & 45 & $\begin{array}{l}\text { Concentration deficits and } \\
\text { muscular weakness }\end{array}$ & Positive & $\begin{array}{l}\text { First sample } \\
\text { positive, second } \\
\text { sample ( } 4 \text { mo } \\
\text { later) negative }\end{array}$ & $+/+/+$ & Definite & $300-700$ \\
\hline $50-55$ & $\mathrm{~F}$ & 14 & $\begin{array}{l}\text { Interferon } \beta-1 \mathrm{a}, 10 \text { y before } \\
\text { fingolimod }\end{array}$ & 18 & $\begin{array}{l}\text { Sensory deficits, hemiparesis, } \\
\text { cognitive impairment, } \\
\text { personality changes, aphasia, } \\
\text { visual impairment, inability to } \\
\text { speak, right-sided weakness } \\
\text { and monoplegia, cortical } \\
\text { blindness }\end{array}$ & Positive & Positive & $+/+/+$ & Definite & $\begin{array}{l}\text { Reported that } \\
\text { there was no } \\
\text { decrease in } \\
\text { ALC }\end{array}$ \\
\hline
\end{tabular}


Table Case details of patients with MS who developed PML after fingolimod treatment (continued)

\begin{tabular}{|c|c|c|c|c|c|c|c|c|c|c|}
\hline $\begin{array}{l}\text { Age } \\
\text { range, y }\end{array}$ & Sex & $\begin{array}{l}\text { MS duration } \\
\text { (at time } \\
\text { of PML } \\
\text { diagnosis), y }\end{array}$ & $\begin{array}{l}\text { Prior treatment for MS; } \\
\text { duration of washout of } \\
\text { prior treatment }\end{array}$ & $\begin{array}{l}\text { Fingolimod } \\
\text { exposure, } \\
\text { mo }\end{array}$ & $\begin{array}{l}\text { Compatible clinical } \\
\text { features }\end{array}$ & $\begin{array}{l}\text { Compatible MRI } \\
\text { findings }\end{array}$ & CSF PCR for JCV & $\begin{array}{l}\text { Clinical } \\
\text { symptoms/ } \\
\text { MRI findings/ } \\
\text { CSF PCR for JCV }\end{array}$ & $\begin{array}{l}\text { Certainty } \\
\text { of PML } \\
\text { diagnosis }\end{array}$ & ALC, cells/ $\mu \mathrm{L}$ \\
\hline $55-60$ & $\mathrm{~F}$ & 19 & $\begin{array}{l}\text { Switched from fingolimod to } \\
\text { natalizumab after washout } \\
\text { period of } 4 \text { wk. On therapy } \\
\text { with natalizumab for } 3 \text { mo at } \\
\text { the time of PML diagnosis }\end{array}$ & 57 & $\begin{array}{l}\text { Personality changes and } \\
\text { unspecified psychiatric } \\
\text { disorder }\end{array}$ & Positive & Positive & $+/+/+$ & Definite & Unknown \\
\hline $50-55$ & M & 11 & $\begin{array}{l}\text { Interferon } \beta \text {-1a, interferon } \\
\beta \text {-1b; washout period } \\
\text { unknown }\end{array}$ & 52 & $\begin{array}{l}\text { Severe visual disturbance in } \\
\text { posterior area on both sides }\end{array}$ & Positive & Positive & $+/+/+$ & Definite & $460-840$ \\
\hline $45-50$ & M & 14 & $\begin{array}{l}\text { Interferon } \beta \text {-1a, interferon } \\
\beta \text {-1b, prednisolone; washout } \\
\text { period unknown }\end{array}$ & 44 & $\begin{array}{l}\text { Aphasia and higher brain } \\
\text { dysfunction, abnormal } \\
\text { speech, ataxia, seizure, } \\
\text { cognitive disorder, and } \\
\text { paralysis }\end{array}$ & Positive & Positive & $+/+/+$ & Definite & $>200$ \\
\hline $40-45$ & $\mathrm{~F}$ & Unknown & $\begin{array}{l}\text { Glatiramer acetate, interferon } \\
\beta-1 \mathrm{a} ; \text { washout period } \\
\text { unknown }\end{array}$ & 65 & $\begin{array}{l}\text { Muscular weakness, cognitive } \\
\text { loss, gait disturbance }\end{array}$ & MRI atypical for PML & $\begin{array}{l}\text { Positive (local lab } \\
\text { and NIH) }\end{array}$ & $+/-/+$ & Probable & $\begin{array}{l}150(\sim 3 \mathrm{mo} \\
\text { before PML } \\
\text { diagnosis) }\end{array}$ \\
\hline $70-75$ & $\mathrm{~F}$ & 35 & $\begin{array}{l}\text { Glatiramer acetate, interferon } \\
\beta-1 \text {; washout period } \\
\text { unknown }\end{array}$ & 58 & $\begin{array}{l}\text { Progressive dysarthria, } \\
\text { dizziness, ataxia, dysphasia, } \\
\text { hemiparesis, memory } \\
\text { impairment }\end{array}$ & Positive & Positive (local lab) & $+/+/+$ & Definite & $420-2,300$ \\
\hline $45-50$ & $\mathrm{~F}$ & 16 & $\begin{array}{l}\text { Glatiramer acetate, } 4 \text { y } \\
\text { corticosteroid pulse therapy; } \\
\text { washout period unknown }\end{array}$ & 84 & $\begin{array}{l}\text { Worsening gait, cognitive } \\
\text { deficits, psychomotor } \\
\text { retardation, dysarthria, } \\
\text { hemiparesis }\end{array}$ & Positive & Positive (local lab) & $+/+/+$ & Definite & $362-970$ \\
\hline
\end{tabular}

Abbreviations: ALC = absolute lymphocyte count; JCV = John Cunningham virus; MS = multiple sclerosis; PML = progressive multifocal leukoencephalopathy. 
months before PML diagnosis. The second patient was receiving fingolimod for 4 years, 6 months, which was discontinued to start natalizumab and was diagnosed with PML 3 months later. Fourteen of the 15 patients were exposed to fingolimod for $>2$ years. Based on the available reported absolute lymphocyte counts in 14 of 15 patients, 4 of the patients exhibited grade 4 lymphopenia $(\leq 200$ cells $/ \mu \mathrm{L})$. Previous MS treatments included natalizumab, interferons, corticosteroids, and glatiramer acetate, with no clinically identifiable patterns.

\section{Virologic characteristics}

To date, there is only limited sequence information on the JCVs associated with PML in fingolimod-treated patients with MS who developed PML.

\section{PML clinical features and diagnosis}

Heralding manifestations of PML at the time of clinical presentations included walking instability, weakness, memory problems, confusion, dysarthria, visual hallucinations, cognitive impairment, speech disturbances, concentration deficits, and visual impairment. One patient was clinically asymptomatic at presentation, and the disorder was diagnosed radiographically. No identifiable pattern was observed in clinical symptoms at presentation.

Brain MRIs were consistent with PML in 13 of the 15 cases and showed varying presentations, ranging from few but extending lesions to multiple lesions extending into adjacent lobes, cortical, subcortical, and juxtacortical regions, and sometimes ill-defined lesions, described with and without microcysts. Some images showed strong hyperintense diffusion-weighted imaging signals, whereas others were without clear diffusion signals.

PCR results for JCV DNA in the CSF were positive in all 15 patients when tested at local laboratories and/or at the NIH reference laboratory (Bethesda, MD). Serology for serum $\mathrm{JCV}$ antibodies was reported for 8 of the 15 patients and was positive in all.

\section{Treatment and clinical outcome}

Treatment with fingolimod was discontinued in all patients, and subsequent therapies for PML included mefloquine, mirtazapine, and cidofovir in varying combinations. Three of the PML cases were fatal. Most patients were reported to be clinically stable or with slightly improving neurologic functions or with deficits including aphasia, mobility, and cognition.

\section{Discussion}

In total, 15 patients with PML occurring in association with fingolimod administration alone were identified in the Novartis safety database, including 12 "definite" and 3 "probable" cases, by August 2017. This included 6 cases that have been published in the literature. ${ }^{13-18}$ The overall rate of
PML with fingolimod treatment is estimated to be $<1: 10,000$ patients, which was considered low risk in a recent article that classified the risk of PML with current disease-modifying therapies. ${ }^{19}$ The current estimated risk of PML with fingolimod treatment is 0.069 (95\% CI: $0.039-0.114$ ) per 1,000 patients and the incidence rate is $3.12 / 100,000$ patient-years.

There are limitations for these risk estimates in that they are solely based on the PML cases spontaneously reported to Novartis from the postmarketing setting. Another potential limitation is the estimate of patient exposure data, which are derived from sales data. PML is a rare, serious opportunistic infection with high awareness in the MS community; thus, the probability of physicians reporting these cases is good. The reporting rate over time has remained constant, thus suggesting that cases of PML are being reported.

In a recent review, ${ }^{19}$ the risk of PML stratified by various disease-modifying therapies used in patients with MS suggested that natalizumab is associated with a significantly higher risk of PML. Fingolimod and dimethyl fumarate are associated with significantly lower risks. Alemtuzumab, mitoxantrone, rituximab, and teriflunomide have a potential risk of PML because all of these agents are associated with the risk of PML when used in treatment regimens/indications other than MS or have a related compound with which PML has been observed. For newer compounds, such as daclizumab and ocrelizumab, clinical experience is very limited and the associated PML risk is unknown. The current risk of PML with fingolimod is very low; to date, only 15 cases have been reported. Moreover, the few cases observed and evaluated so far do not allow the identification of any evidence-based specific guidance to form monitoring and risk-mitigation strategies for fingolimod. However, certain risk mitigation strategies have been proposed for other drugs with a larger number of such cases or a potentially clearer correlation with their mode of action, such as routine JCV antibody testing or specific lymphocyte cutoffs. However, the value of such guidance systems and their ability to prevent additional PML cases is yet to be proven. So far, the risk stratification algorithm has not led to any marked reduction in the incidence of PML in natalizumab-treated patients. ${ }^{20}$ Another previous report suggested that, although a decrease in the incidence of PML has not been noted, the rate of incidence increase has certainly reduced significantly between 2013 and 2016, after the introduction of the Stratify JCV assay. ${ }^{21}$ Nevertheless, JCV antibody status should be retested regularly considering the false-negative rates and the potential for seroconversion. ${ }^{22,23}$

The number of PML cases reported so far with fingolimod is too low to trigger any specific interventions at this point in time. Guidelines that are not evidence-based may result in an additional burden for patients with uncertain benefits, including the risk of inappropriate modification of an effective MS therapy, which in itself carries the risk of increasing morbidity in such patients. At present, no PML risk 
stratification methodology has been identified for patients treated with fingolimod. However, risk mitigation is focused on increased awareness and education of patients and prescribers regarding such cases because, in most instances, early diagnosis and appropriate management are key to improved therapeutic outcomes.

The clinical signs and symptoms of PML often resemble those observed with an MS relapse; however, in contrast to an MS relapse, these tend to be slowly and persistently progressive in nature. Physicians should keep this in mind when investigating patients for PML and must look for features that distinguish PML from other differential diagnoses including MS. In a PML case series consisting of 28 patients, ${ }^{24}$ typical clinical presentation included neurobehavioral, motor, language, and visual symptoms, with cognitive changes being more prominent. Acute or subacute cognitive changes, language disturbances, and seizures should serve as "red flags" for the possibility of PML. Optic neuritis and myelopathy would not be anticipated as clinical manifestations of PML.

MRI scans offer a sensitive tool in the diagnosis of PML. Typical PML lesions are diffuse, subcortical, and located exclusively in the white matter. These lesions appear as single or multiple hyperintense areas in T2-weighted images, which become confluent and large with disease progression. MRI contrast enhancement is believed to be minimal or absent in $\mathrm{PML}^{25}$; however, in AIDS-associated PML, $10 \%$ of patients exhibited contrast enhancement on CT scans and $15 \%$ on MRI with gadolinium. ${ }^{26}$ In natalizumab-associated PML, 43\% of cases showed gadolinium contrast enhancement at the time of diagnosis. ${ }^{24}$ Although contrast enhancement alone cannot be used as a feature to distinguish an MS relapse from PML, patterns of contrast enhancement, the nature and location of the lesions, and the presence of a dark rim around the lesions on susceptibility weighted imaging or gradient echo imaging may be helpful in distinguishing the demyelinating lesions of PML from those of MS. ${ }^{27,28}$

As of August 2017, approximately 217,000 patients have been treated with fingolimod in both clinical trials and postmarketing settings, and the total patient exposure exceeds 480,000 patient-years. Although the risk of PML with fingolimod treatment is considered very low, vigilance toward PML is required for all patients irrespective of the low risk. The current understanding of the mechanism of action of fingolimod does not provide a convincing causal link between fingolimod treatment and the incidence of PML. Fingolimod has been shown to prevent the egress of $\mathrm{CCR} 7^{\text {ve }}$ naive $\mathrm{T}$ cells and central memory $\mathrm{T}$ cells from lymph nodes, sparing $\mathrm{CCR}^{-\mathrm{ve}}$ effector memory $\mathrm{T}$ cells. ${ }^{29}$ The redistribution of $\mathrm{CD}^{+}{ }^{+}$central memory $\mathrm{T}$ cells from circulation to lymphatic organs may contribute to the development of PML. In some cases, because of its partial sequestration of effector memory $\mathrm{T}$ cells, fingolimod may have a contributory role to other factors in reducing immune response to JCV reactivation. Isolating and fully characterizing the viruses in cases of fingolimod-associated PML may assist in understanding the disease pathogenesis with fingolimod.

Based on available data, there appear to be no clinically or radiographically unique features of fingolimod-associated PML. The sex distribution is concordant with the overall fingolimod-treated population. Ten of the 15 patients were older than 50 years at the time of PML diagnosis. Although an exact relationship with fingolimod treatment duration cannot be elucidated, all 15 cases occurred after 18 months or more of treatment. There appears to be no correlation with profound lymphopenia and lymphocyte subsets (CD4, CD8, and CD4/ 8 ratios) in fingolimod-treated patients, and this is not believed to be informative of PML risk. Treating physicians should be vigilant for signs and symptoms suggestive of PML in all patients who are being treated with fingolimod. As soon as PML is suspected, the drug should be discontinued until it has been ruled out. Early diagnosis is critical for better clinical outcomes. Unfortunately, there is no established treatment for $\mathrm{PML},{ }^{30}$ and at this point of time, no treatment recommendations can be made based on the limited number of cases seen.

\section{Author contributions}

All authors contributed to the design, data collection, data analysis, and interpretation, and provided critical review during the preparation of the manuscript. All authors edited the manuscript for intellectual content, provided guidance during manuscript development, and approved the final version submitted for publication. The final responsibility for the content lies with the authors.

\section{Acknowledgment}

The authors thank Sreelatha Komatireddy (Novartis Healthcare Pvt. Ltd., Hyderabad, India) for assistance with formatting the manuscript.

\section{Study funding}

No targeted funding reported.

\section{Disclosure}

J. Berger reports grants from Biogen and TEVA; personal fees from Biogen, Genentech/Roche, Genzyme, Millennium/ Takeda, Novartis, Inhibikase, Excision Bio, Roche, Amgen, AstraZeneca, Alkermes, and Bayer. B. Cree reports personal fees from Biogen, EMD Serono, GeNeuro, Novartis, and Sanofi Genzyme. B. Greenberg reports personal fees from Novartis, Alexion; grants from MedImmune, Chugai, and Genentech. B. Hemmer reports grants from Chugai, Roche, and MedImmune; personal fees from Roche and Allergy Therapeutica; personal fees and nonfinancial support from Biogen, Merck, Bayer, and Teva. He was funded by the German MS Competence Network, the Transregional Research Center TR118, and the EU project Multiple MS. B. Ward reports personal fees from Novartis. V. Dong is an employee of Novartis. M. Merschhemke is an employee of Novartis. Go to Neurology.org/N for full disclosures. 
Received November 13, 2017. Accepted in final form February 27, 2018.

\section{References}

1. Palazzo E, Yahia SA. Progressive multifocal leukoencephalopathy in autoimmune diseases. Joint Bone Spine 2012;79:351-355.

2. Kleinschmidt-DeMasters BK, Tyler KL. Progressive multifocal leukoencephalopathy complicating treatment with natalizumab and interferon beta-1a for multiple sclerosis. N Engl J Med 2005;353:369-374.

3. Langer-Gould A, Atlas SW, Green AJ, Bollen AW, Pelletier D. Progressive multifocal leukoencephalopathy in a patient treated with natalizumab. N Engl J Med 2005;353:375-381.

4. Van Assche G, Van Ranst M, Sciot R, et al. Progressive multifocal leukoencephalopathy after natalizumab therapy for Crohn's disease. N Engl J Med 2005;353:362-368.

5. Tysabri Safety Update [online]. Available at: medinfo.biogen.com/secure/download? doc=workspace $\% 3 \mathrm{~A} \% 2 \mathrm{~F} \% 2 \mathrm{FS}$ pacesStore $\% 2 \mathrm{Fa} 22$ baae $1-7220-416 \mathrm{c}-8 \mathrm{c} 2 \mathrm{c}-28 \mathrm{c} 42 \mathrm{c}$ dacff \& type $=$ pmldoc $\&$ path $=$ null $\&$ dpath $=$ null $\&$ mimeType $=$ null $\&$ Continue $=$ Continue. Accessed July 21, 2017.

6. Biogen. Tecfidera (Dimethyl Fumarate): PML Case Reports. Available at: medinfo. biogen.com. Accessed January 9, 2017.

7. Brinkmann V, Davis MD, Heise CE, et al. The immune modulator FTY720 targets sphingosine 1-phosphate receptors. J Biol Chem 2002;277:21453-21457.

8. Mandala S, Hajdu R, Bergstrom J, et al. Alteration of lymphocyte trafficking by sphingosine-1-phosphate receptor agonists. Science 2002;296:346-349.

9. Cohen JA, Barkhof F, Comi G, et al. Oral fingolimod or intramuscular interferon for relapsing multiple sclerosis. N Engl J Med 2010;362:402-415.

10. Kappos L, Radue EW, O’Connor P, et al. A placebo-controlled trial of oral fingolimod in relapsing multiple sclerosis. N Engl J Med 2010;362:387-401.

11. GILENYA [prescribing information]. Available at: www.pharma.us.novartis.com/ product/pi/pdf/gilenya.pdf. Accessed May 18, 2017.

12. Berger JB. Progressive multifocal leukoencephalopathy. In: Tselis AC,Booss J, editors. Handbook of Clinical Neurology. Amsterdam: Elsevier B.V.; 2014:357-376.

13. Gyang TV, Hamel J, Goodman AD, Gross RA, Samkoff L. Fingolimod-associated PML in a patient with prior immunosuppression. Neurology 2016;86:1843-1845.

14. Calzado G, Virgós T, Bullejos M, et al. Progressive multifocal leukoencephalopathy associated with fingolimob use in a patient with multiple sclerosis without previous exposure to immunosuppressant drugs. Eur J Hosp Pharm 2016;23:A156.

15. Kume K, Takada T, Kawakita R, et al. A case of progressive multifocal leukoencephalopathy in a patient who was receiving fingolimod. Neurol Ther 2016;33:S253.
16. Nakahara J, Kufukihara K, Tanikawa M, et al. Third Japanese case of fingolimodassociated PML in natalizumab-naive MS: coincidence or alarm bell? (P762). Mult Scler J 2017;23 (Suppl 3):382-3.

17. Nishiyama S, Misu T, Shishido-Hara Y, et al. Fingolimod-associated PML with mild IRIS in MS. Neurol Neuroimmunol Neuroinflamm 2018;5:e415.

18. Rossi F, Turazzini M, Ricci S, et al. Progressive multifocal leucoencephalopathy in patient with fingolimod treatment: one-year follow-up. Mult Scler J 2017;23:680-975.

19. Berger JR. Classifying PML risk with disease modifying therapies. Mult Scler Relat Disord 2017;12:59-63.

20. Cutter GR, Stuve O. Does risk stratification decrease the risk of natalizumab associated PML? Where is the evidence? Mult Scler 2014;20:1304-1305.

21. Campagnolo D, Dong Q, Lee L, Ho PR, Amarante D, Koendgen H. Statistical analysis of PML incidences of natalizumab-treated patients from 2009 to 2016: outcomes after introduction of the Stratify JCV ${ }^{\circledast}$ DxSelect ${ }^{\mathrm{TM}}$ antibody assay. J Neurovirol 2016;22: 880-881.

22. Gorelik L, Lerner M, Bixler S, et al. Anti-JC virus antibodies: implications for PML risk stratification. Ann Neurol 2010;68:295-303.

23. Outteryck O, Zephir H, Salleron J, et al. JC-virus seroconversion in multiple sclerosis patients receiving natalizumab. Mult Scler 2014;20:822-829.

24. Clifford DB, De Luca A, Simpson DM, Arendt G, Giovannoni G, Nath A. Natalizumab-associated progressive multifocal leukoencephalopathy in patients with multiple sclerosis: lessons from 28 cases. Lancet Neurol 2010;9:438-446.

25. Sahraian MA, Radue EW, Eshaghi A, Besliu S, Minagar A. Progressive multifocal leukoencephalopathy: a review of the neuroimaging features and differential diagnosis. Eur J Neurol 2012;19:1060-1069.

26. Berger JR, Pall L, Lanska D, Whiteman M. Progressive multifocal leukoencephalopathy in patients with HIV infection. J Neurovirol 1998;4:59-68.

27. Yousry TA, Pelletier D, Cadavid D, et al. Magnetic resonance imaging pattern in natalizumab-associated progressive multifocal leukoencephalopathy. Ann Neurol 2012;72:779-787.

28. Hodel J, Outteryck O, Verclytte S, et al. Brain magnetic susceptibility changes in patients with natalizumab-associated progressive multifocal leukoencephalopathy. AJNR Am J Neuroradiol 2015;36:2296-2302.

29. Mehling M, Brinkmann V, Antel J, et al. FTY720 therapy exerts differential effects on T cell subsets in multiple sclerosis. Neurology 2008;71:1261-1267.

30. Williamson EML, Berger JR. Diagnosis and treatment of progressive multifocal leukoencephalopathy associated with multiple sclerosis therapies. Neurotherapeutics 2017;14:961-973. 


\section{Progressive multifocal leukoencephalopathy after fingolimod treatment}

Joseph R. Berger, MD, Bruce A. Cree, MD, PhD, MAS, Benjamin Greenberg, MD, Bernhard Hemmer, MD, Brian J. Ward, MDCM, Victor M. Dong, MD, and Martin Merschhemke, MD

Cite as: Neurology ${ }^{\circledR}$ 2018;90:e1815-e1821. doi:10.1212/WNL.0000000000005529
Correspondence

Dr. Berger

joseph.berger@

uphs.upenn.edu

\section{Study question}

What is the estimated risk and incidence of progressive multifocal leukoencephalopathy (PML) after fingolimod treatment?

\section{Summary answer}

There is a low risk of PML after fingolimod treatment in the absence of prior natalizumab treatment.

\section{What is known and what this paper adds}

Evidence suggests an increased risk of PML in patients with multiple sclerosis who are treated with immunosuppressive or immunomodulatory agents. The present study determined the risk of PML after fingolimod use and suggests that fingolimod-associated PML is relatively rare and does not have unique clinical or radiographic features.

\section{Participants and setting}

The study identified 15 patients with fingolimod-associated PML (12 definite cases and 3 probable cases) in the overall population of patients treated with fingolimod as documented in the Novartis safety database.

\section{Design, size, and duration}

Safety database data were used to generate a risk estimate and incidence of PML among patients treated with fingolimod. Patients with fingolimod-associated PML were characterized in terms of age, disease characteristics, comorbidities, and previous medications including natalizumab treatment.

\section{Primary outcomes}

Three of the PML cases were fatal. Most patients were reported to be clinically stable; had slightly improving neurologic functions; or had deficits including aphasia, mobility, and cognition.

\begin{tabular}{lll}
\hline $\begin{array}{l}\text { Age range } \\
\text { (y) }\end{array}$ & $\begin{array}{l}\text { Fingolimod exposure } \\
\text { (mo) }\end{array}$ & Certainty of PML diagnosis \\
\hline Median: 53 & Ranged from 18 to 65 & $\begin{array}{l}\text { All but one patient was } \\
\text { symptomatic at the time of } \\
\text { diagnosis }\end{array}$ \\
\hline
\end{tabular}

\section{Main results and the role of chance}

The estimated risk of PML in patients treated with fingolimod was 0.069 per 1000 patients (95\% CI: 0.039-0.114) with an incidence of 3.12 per 100,000 patient-years (95\% CI: 1.75-5.15). Among 15 patients who developed PML, 11 were women and 14 had received fingolimod treatment for $>2$ years. Two patients had a history of natalizumab treatment; however the contributory role of fingolimod could not be excluded. No patient exhibited sustained grade 4 lymphopenia.

\section{Bias, confounding, and other reasons for caution}

Risk estimation in this study was solely based on cases of PML that were spontaneously reported to Novartis during postmarket surveillance. Additionally, patient exposure data were estimated from both clinical trial data and estimated worldwide sales volume (kilogram of active substance).

\section{Generalizability to other populations}

The results of the present study are generalizable to all patients receiving treatment with fingolimod.

\section{Study funding/potential competing interests}

The authors report financial support from Biogen, TEVA, Chugai, Roche, Medimmune, German MS Competence Network, the transregional research center TR118, and the EU project Multiple MS. Victor M. Dong and Martin Merschhemke are employees of Novartis. Go to Neurology.org/N for full disclosures. 


\section{Neurology}

\section{Progressive multifocal leukoencephalopathy after fingolimod treatment \\ Joseph R. Berger, Bruce A. Cree, Benjamin Greenberg, et al. \\ Neurology 2018;90;e1815-e1821 Published Online before print April 18, 2018 \\ DOI 10.1212/WNL.0000000000005529}

This information is current as of April 18, 2018

\section{Updated Information \& Services}

References

Citations

Subspecialty Collections

Permissions \& Licensing

Reprints including high resolution figures, can be found at: http://n.neurology.org/content/90/20/e1815.full

This article cites 26 articles, 5 of which you can access for free at: http://n.neurology.org/content/90/20/e1815.full\#ref-list-1

This article has been cited by 5 HighWire-hosted articles: http://n.neurology.org/content/90/20/e1815.full\#\#otherarticles

This article, along with others on similar topics, appears in the following collection(s):

Multiple sclerosis

http://n.neurology.org/cgi/collection/multiple_sclerosis

Viral infections

http://n.neurology.org/cgi/collection/viral_infections

Information about reproducing this article in parts (figures,tables) or in its entirety can be found online at:

http://www.neurology.org/about/about_the_journal\#permissions

Information about ordering reprints can be found online:

http://n.neurology.org/subscribers/advertise

Neurology ${ }^{\circledR}$ is the official journal of the American Academy of Neurology. Published continuously since 1951, it is now a weekly with 48 issues per year. Copyright Copyright ( 2018 The Author(s). Published by Wolters Kluwer Health, Inc. on behalf of the American Academy of Neurology.. All rights reserved. Print ISSN: 0028-3878. Online ISSN: 1526-632X.

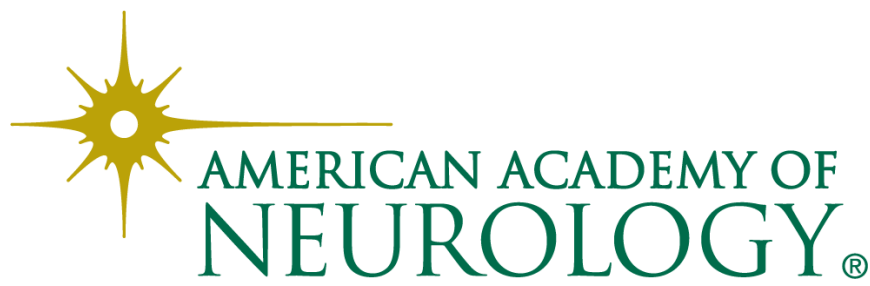

